\title{
Burden and Standard of Proof in Election Petitions without Criminal Allegations
}

\author{
F. O. Osadolor \\ ${ }^{1}$ Department of Public Law, Faculty of Law, University of Benin, Benin City, Nigeria \\ Correspondence: F. O. Osadolor, Department of Public Law, Faculty of Law, University of Benin, Benin City, \\ Edo State, Nigeria. E-mail: faith.osadolor@uniben.edu
}

Received: May 26, 2019

doi:10.5539/jpl.v12n3p156
Accepted: July 6, 2019 Online Published: August 30, 2019

URL: https://doi.org/10.5539/jpl.v12n3p156

\begin{abstract}
The burden and standard of proof in election petition without criminal allegation is in tandem with the extant Evidence Act, as election petitions is sui generis. The purpose of election laws is to obtain a correct expression of the intent of the voters. However, this paper argues that whereas proof of election petition without criminal allegations requires proof on the preponderance of evidence, the shallow chant of "he who asserts must prove" in the extant law is a conduit pipe for electoral injustice. This paper therefore makes a clarion call for the amendment of the relevant extant law to usher in a legal regime of burden of proof on the pleadings, where whoever asserts the affirmative or positive must prove on the state of the pleadings.

The rebuttable presumption of the regularity of the conduct of elections and declaration of results, no longer serve the end of justice in our electoral process. This paper therefore argues that the Electoral Act be amended to place the burden of proof of the regularity of elections and declaration of results on the Independent National Electoral Commission (INEC), to meet the desired justice contemplated in the electoral process.
\end{abstract}

Keywords: election, burden of proof, standard of proof, Nigeria, right to vote

\section{Introduction}

"In Nigeria, it may be apt to describe the right to vote as a constitutional right since it is conferred by the Constitution. The Constitution (under a democratic arrangement) and the electoral enactments provide the basis for the exercise of the right to vote". ${ }^{2}$

In the determination of any form of litigation submitted for adjudication, one fundamental question that must arise is that of who bears the burden of proof of the case. ${ }^{2}$ The utmost determination of this question is fundamental because if the party on whom the burden of proof lies fails and or neglects to discharge the burden of proof in a case, the party is confronted with risk of losing the case. In Gundiri v. Nyako, ${ }^{3}$ for instance, the petitioners failed because they were unable to discharge the burden of proof on them for their failure to call their polling agents as witnesses of what transpired at the polling station. The court categorically declared that where non-compliance with the Electoral Act is alleged, it raises the mandatory duty on the Petitioner to call their polling agents in proof of the allegation. This must however be read in the light of Okechukwu v. INEC, ${ }^{4}$ where the Supreme Court held that a polling agent can only testify on what transpired that he saw within his own polling unit and that being a human being, he can only be physically present at only one polling unit at any given time.

\section{General Burden of Proof}

Generally, the phrase "burden of proof" refers to the obligation on a litigant to adduce evidence of a contested allegation of fact before a court of law or other judicial or quasi-judicial tribunals. In the nutshell, burden of proof imposes a mandatory obligation on a litigant to prove or disprove what is alleged to be true.

\footnotetext{
${ }^{1}$ Epiphany Azinge, Right to Vote in Nigeria: A Critical Commentary on the Open Ballot System, The, 38 J. Afr. L. 173 (1994) 174

${ }^{2}$ T.A. Aguda, The Nigerian Law of Evidence, $4^{\text {th }}$ edn (Lagos: Spectrum, 2002), 154.

3 [2014] 2 NWLR (Pt. 1391) 211, SC

${ }^{4}$ 2014, 17 NWLR (Pt1436) 255, 294-295
} 
It is pertinent to note that different legal scholars see the burden of proof from different perspectives. ${ }^{5}$ J.B. Thayer ${ }^{6}$ took the view that the phrase "burden of proof" could be seen from two different perspectives. The first perspective is that it places a peculiar duty on the party who has the risk of any given proposition on which parties are at issue; the party who will lose the case if he does not make the proposition out, when all has been said and done. ${ }^{7}$ Thayer's second perspective of burden of proof is that it means " $[t]$ he duty of going forward in argument or a case, or at any later movement throughout the trial or discussion". 8 Phipson also gave two meanings to the phrase "burden of proof" as applicable to judicial proceedings, namely; the burden of proof as a matter of law and pleading and the burden of proof in the sense of adducing, "the duty of going forward in argument or in producing evidence whether at the beginning of a case, or at any later moment throughout the trial or decision". ${ }^{10}$ The same two meanings of the legal burden or burden of proof simpliciter and the evidential burden resonated in Cross ${ }^{11}$ view. The same approach is discoverable from other scholars. According to Rolin M. Parkins and Ronald N. Boyce: ${ }^{12}$

In the past, the term "burden of proof" has been used in two different senses: (1) The burden of going forward with the evidence. The party having this burden must introduce some evidence if he wishes to get a certain issue into the case. If he introduces enough evidence to require consideration of this issue, this burden must be met (2) burden of proof in the sense of carrying the risk of non-persuasion. The one who has the burden stands to lose if his evidence fails to convince the jury or the Judge in a non-jury trial. The present trend is to use the term "burden of proof" only with this second meaning.... ${ }^{13}$

William D. Hawkland ${ }^{14}$ made a similar submission on the phrase, "burden of proof" as follows:

The expression "burden of proof" is tricky to mean various things. Strictly speaking, burden of proof denotes the duty of establishing by a fair preponderance of the evidence the truth of the operative facts upon which the issue at hand is made to turn by substantive law. Secondary sense to mean the burden of going forward with the evidence. In this sense, it is sometimes said that a party has the burden of countering with evidence a prima facie case made against that party. ${ }^{15}$

It is thus obvious from the above that though different scholars use different nomenclature, they all tend towards the common theme of the duty to adduce evidence in support of a claim in court. For instance, Phipson's burden of proof as a matter of law and pleading is one and the same as Cross's legal burden or burden of proof simpliciter. In the same vein, Phipson's burden of proof in the sense of adducing evidence relates to Cross's evidential burden.

This incidentally is the approach followed by Nigerian courts as well as in the Nigerian Evidence Act. Ezemba v. Ibeneme, ${ }^{16}$ the Supreme Court of Nigeria affirmed that:

In civil cases, the phrase "burden of proof has two distinct and frequently confused meanings. Firstly, it may mean the burden of proof as a matter of law and the pleadings usually referred to as the legal burden or the burden of establishing a case; secondly, the burden of proof in the sense of adducing evidence often referred to as the evidential burden. While the burden of proof in the first sense is always stable or static, the burden of proof in the second sense may shift constantly as one scale of evidence or the other preponderates.

\footnotetext{
${ }^{5}$ Cross R (2000), Cross on Evidence, (4 ${ }^{\text {th }}$ ed.), London: Butterworths, 73.

${ }^{6}$ J.B. Thayer, (1898), Preliminary Treatise on Evidence at the Common Law, Boston: Little, Brown,.

${ }^{7}$ Ibid., 65 .

${ }^{8}$ Ibid.

${ }^{9}$ Phipson on Evidence, $\left(1976,12^{\text {th }}\right.$ ed.) London: Sweet and Maxwell

${ }^{10}$ Ibid., 37

${ }^{11}$ R. Cross, Cross on Evidence, above, note5, p. 73.

${ }_{12}$ Rolin M. Parkins and Ronald N. Boyce, (1982) Criminal Law, (3d ed), Mineola: The Foundation Press

${ }^{13}$ Ibid., 78

${ }^{14}$ Uniform Commercial Code series 2A-516:08 (1984)

${ }^{15}$ Ibid.

${ }^{16}$ NSCQR VOLUME 192004 Page 355, 372, reiterating the earlier view of the court in Elemo and Others v. Omolade and Others, (1968) 1 NWLR, 359, 361
} 
It is submitted that the incontrovertible inference from the above analysis on the phrase, burden of proof is that technically, the phrase refers to two distinct types of burdens, namely: the legal burden and the evidential burden. The legal burden is the obligation of a party to prove or disprove a contested fact either by preponderance of evidence or beyond reasonable doubt, whichever is applicable. ${ }^{17}$ Ipso facto, a litigant certainly loses his case if he fails to discharge the legal burden of proof. The courts decide the paramount question whether a party has discharged the legal burden only at the conclusion of the trial. Against this background, the legal burden generally, usually lies on one of the parties and does not shift to the other party throughout the length and breadth of the trial. ${ }^{18}$ On the other hand, evidential burden refers to the obligation on a party to adduce sufficient evidence of a particularly contested fact in order to justify a decision on that fact in his favour. A litigant who fails to discharge the evidential burden in a case carries the risk, but not the certainty of losing the whole or some part of the case. Furthermore, unlike the legal burden, the evidential burden is not static: it keeps shifting between the parties throughout the course of the trial. ${ }^{19}$

The court of appeal in the case of Arum v. Nwobodo, ${ }^{20}$ drew a worthy distinction between "burden of proof" and "evidential burden". The Court puts it aptly thus:

There is a distinction between the "burden of proof" in a case and the "evidential burden" in a case. The former, as an inflexible rule, rests on the plaintiff in civil matters while the latter is the onus of proof on one making a specific assertion over a particular point essential to his case regardless of whether the person making the assertion is the defendant. ${ }^{21}$

The Court went further to situate the perception of evidential burden on specific provisions of the Evidence Act, ${ }^{22}$ as follows:

The evidential burden in a suit imports that where a given allegation, whether affirmative or negative, forms an essential part of a party's case, the onus of proof of such allegation rest on that party. The evidential burden is thus complimentary to the general principle of burden of proof that has its origin in sections 135, 136 and 137 of the Evidence Act CAP E14 2004 and whenever its application is warranted, it is said that the burden of proof to establish a particular assertion has shifted.

As earlier mentioned, the approach of Nigerian courts is anchored on the provisions of sections 131 and 132 of the Evidence Act. Section 131(1) and (2) provides that he who asserts the existence of the existence of facts must prove that they exist, and that the burden of proof lies on a person who alleges the existence of the facts. Importantly, by section 132, "[t]he burden of proof in a suit or proceedings lies on that person who would fail if no evidence at all were given on either side." By section 133, the burden of first proving the existence or non-existence of a fact lies on the party against whom the judgement of the court would be given if no evidence were produced on either side, regard being had to any presumption that may arise on the pleadings.

\subsection{Burden of Proof in Civil Cases}

The burden of proof in civil cases is regulated by the combined provisions of sections 131, 132 and 133 of the Act, as set out above. In a plethora of cases, Nigerian courts have given judicial expressions to the above principles enshrined in sections 131, 132 and 133 of the Evidence Act.

The case of Onwuka v. Omoigui ${ }^{23}$ restated the general rule in civil cases that the burden of proof rests upon the party who substantially asserts the affirmative before adducing evidence. In other words, the burden of proof lies on the person who will fail assuming no evidence is adduced on either side. In Songhai Limited v. United Bank for Africa, ${ }^{24}$ it was held that "the basic principle governing the incidence of burden of proof is that the obligation of going further if he wishes to win, rests".

\footnotetext{
${ }^{17}$ C. Tapper, (2010) Cross and Tapper on Evidence, $\left(12^{\text {th }}\right.$ ed), New York: Oxford University Press, 121.

18 Afe Babalola, (2001), Law and Practice of Evidence in Nigeria, Siban Books Limited, 87

${ }^{19}$ Handbook on Election Disputes in Kenya (2013), Nairobi: Law Society of Kenya and the Judiciary, p. 8

${ }^{20}$ (2004) 9 NWLR pt. 878, 411

${ }^{21}$ Ibid.

${ }^{22}$ It was then the Evidence Act CAP E14 Laws of the Federation of Nigeria, 2004, now the Evidence Act, 2011.

23 (1992) 3 NWLR pt. 230, 393; Ojukwu v. Obasanjo, (2003) FWLR (pt. 182) 1766. Also, Sokoto Furniture Factory Ltd. v. Societe Generale Bank (NIS) Ltd, (2003) FWLR pt. 186, 693 at 706; Olowu v. Obako (1985) 3 NWLR pt. 13, 372; Abiodun v. Aderin (1962) All NLR 350; Chiroma v. Suwa (1986) 1 NWLR pt. 19, 751

${ }^{24}$ (2004) FWLR pt. 189, 1244, 1258.
} 
It is therefore trite law that the burden in civil cases is generally, always but not invariably, on the claimant. It was against this legal background that the Court held in the case of Nwaga v. Registered Trustees Recreation $C l u b,{ }^{25}$ that "the onus is on the plaintiff to adduce credible evidence to prove his case before it becomes necessary for the defendant to call evidence to rebuff the plaintiff's assertion". Ipso facto, the plaintiff cannot succeed by reason of the weakness of the defendant's case; it is a plaintiff's duty to show that he is entitled to judgment based on the evidence adduced by them at the trial.

\section{Standard of Proof in Civil Cases}

The standard of proof is to all intent and purposes the level of proof which the court requires before it can reach a conclusion that a litigating party before it has discharged the burden of proof placed on such litigant. It is therefore the level of acceptability of evidence before it, in order to give judgement in favour of such party. ${ }^{26}$ In the law of evidence, there are two different standards. The standard of proof in criminal cases differs from civil cases.

The standard of proof required in civil cases is proof on the balance of probability or preponderance of evidence. The Supreme Court of Nigeria, in the classical case of Mogaji v. Odofin ${ }^{27}$ indicated how the decision on the balance of probability or preponderance of evidence can be reached. According to the Court:

The judge should first of all put the totality of the testimony adduced by both parties on an imaginary scale. He should then put the evidence of the plaintiff on one side of the imaginary scale and put the evidence of the defendant on the other side of the scale. The judge is then expected to weigh the two pieces of evidence together. The judge is then to decide which of the two pieces of evidence is heavier. This is not to be decided by the number of witnesses called but by the quality and probative value of the testimony of the witnesses. The admissibility, relevance, credibility and conclusiveness of the evidence will naturally help the judge in coming to the conclusion in favour of one party against the other. ${ }^{28}$

In the course of this judicial exercise, the court need not search for the exact mathematical calculus in the weighing machine, as no figure borne out of the calculus exist with mathematical precision, rather the judge relies on his judicial and judicious mind in determining where the imaginary scale tilts. This was again brilliantly and figuratively expressed by Eso JSC in the State v. Aibangbe, ${ }^{29}$ as follows;

For, be it noted, a court of law is a court of cold facts and law and not a court of fiction. Fiction belongs to Alice in Wonderland, facts belong to the court where the judge, almost invariably, sees in his mind a scale, hence it is called an imaginary scale. He feeds facts into either scale, depending on which side gives the evidence. In a criminal case, until the prosecution weighs right down the judge does not convict. In a civil case the judge measures the delicacy of the tilting scale at the time he assesses the evidence. The tilt may be slight yet he gives judgement for the side to whom it tilts. If there is no evidence fed into one of the scales, then it is for whom the bell tolls... It tolls for the empty scale, for eminently, the slightly fed scale wins against the empty scale.

The imaginary scale measure is not a ritualistic exercise that bears not on the justice of the case; it is an intricate part of the judicial process and which weighs heavily on the eventual decision the court would take in seeking to achieve substantive justice in the case at bar. As succinctly stated by the Supreme Court in Dibiamaka v. Osakwe: $:^{30}$

This scale though imaginary is still the scale of justice and the scale of truth, such scale will automatically repel any and all false evidence. What ought to go into that scale should therefore be no other than credible evidence. What is therefore necessary in deciding what goes into the imaginary scale is the value, credibility and quality as

${ }^{25}$ (2004) FWLR pt. 190, 1360, 1376.

26 A.C. Akintola and A.A Adedeji (eds.), (2006), Nigerian Law of Evidence (Ibadan: University of Ibadan Press, 65

27 (1978) 4 SC 91.

${ }^{28}$ This decision has been cited with approval and followed in preponderance of cases. See Buhari v Independence National Electoral Commission (INEC), NSCQR, Vol 36 (2018) 489

${ }^{29}$ (1988) 7 SC 1, 154, 168, 169.

${ }^{30}$ (1989) SCNJ 30. 
well as probative essence of the evidence. If any evidence is disbelieved then such evidence has no probative value and should therefore not go into the imaginary scale.

It must be borne in mind in that the justice of the case is not determined by the number of witnesses called by a party - justice is not for the party who controls the $\mathrm{mob}^{31}$ - but for the party that who is also to proof their case, by the best evidence even of a lone witness. This is in tandem with the view of the Court of Appeal in Akanniv. Odejide, ${ }^{32}$ where it declared:

A civil case is decided on preponderance of evidence. The decision having to be on balance of probability, the trial court has to place the evidence of the parties on an imaginary scale and determine which of the evidence outweighs the other. In such exercise, it is not the number of witnesses that is used in determining the balance but the probative value of the evidence. That is, the trial court would have regard only to whether the evidence is admissible, relevant, credible, conclusive and more probable than that adduced by the other party. Consequently, the degree of preponderance of evidence may be less where a civil case is uncontested.

The court ipso facto evaluates the evidence. The trial court is in the best position to evaluate the evidence of witnesses because of the exclusive advantage of seeing the witnesses, their comportment and demeanour in the witness box. ${ }^{33}$ This was echoed by the Court of Appeal in the case of Oluwole v. Abubakare. ${ }^{34}$

\section{Nature of Election Petitions and Burden of Proof}

Election petition cases are within the realm of civil proceedings. However, they are not seen as civil proceedings in the ordinary sense nor are they treated as normal civil proceedings. Uwaifo JSC stated in the case of Buhari v. Yusuf,$^{35}$ that election petitions are distinct from the ordinary civil proceedings and in certain circumstances, the slightest default in complying with procedural step which otherwise could either be cured or waived in ordinary civil proceedings could result in fatal consequences to the petition. In the words of his Lordship, "an election petition is neither seen as a civil proceedings in the ordinary sense nor, of course, a criminal proceeding. It can be regarded as a proceeding sui generis". In Obih v. Mbakwe, Kalgo JSC categorically postulated that:

There is no doubt at all that an election petition is not to be treated under peculiar provisions of the relevant electoral law and is not particularly related to the ordinary rights and obligations of the parties concerned. ${ }^{36}$

It thus follows that as election matters are sui generis and do not deal with the civil rights and obligations of parties, they are not such that are properly within the jurisdiction of the High Court. In the case Orubu v. NEC, ${ }^{37}$ the Appeal Court held that election petitions are peculiar in nature, and because of this peculiarity and importance to the wellbeing of a democratic society, they are "[r] egarded with aura that places them over and above normal day to day transaction between individuals which give rise to ordinary claims in Court". Oguntade JCA restated this judicial position in the case of Abdullahi v. Elayo ${ }^{38}$ where he declared that:

It must also be borne in mind that an election is not always to be treated as the ordinary civil suits in Court. An election legislation creates a special jurisdiction and the ordinary rules of procedure in civil cases do not always serve to effectuate its purposes.

The plethora of judicial authorities on the nature and peculiarities of election petition agree only to the extent that it is civil proceedings, but, in a unique and peculiar class of its own, that it is not to be treated as a normal civil proceedings. It is therefore distinct in nature and procedure from other civil proceedings. It therefore means of its own kind or class; unique or peculiar. Election petitions therefore belong to a special class of their own and enjoy special treatment by the constitution and under the law regulating the practice and procedure in civil

\footnotetext{
${ }^{31}$ Indeed, "[n]o witness who has given on oath two material inconsistent evidence is entitled to the honour of credibility. Such a witness does not deserve to be treated as a truthful witness" - M. S. C. Ezemba v. Ibeneme NSCQR vol. 19 (2004), 355, 373

32 (2004) 9 NWLR pt. 879, 575.

${ }^{33}$ Faith O. Osadolor, (2004), Source Book on the Law and Practice of Evidence in Nigeria (Benin: Churchill Printing and Publishing Ltd., p. 50.

${ }^{34}$ (2004) 10 NWLR pt. 882, 549

35 (2003) 14 NWLR pt. 841 446; (2005) 1 LRECN, 481, 488.

36 (1981-1990) LRECN 197.

${ }^{37}$ (1988) 5 NWLR pt. 94, 323, 347; (1981-1990) LRECN 550.

38 (1993) 1 NWLR pt. 268, 171, 19.
} 
proceedings.

The peculiar nature of election petitions lies in the fact, inter alia, that the right of access to election tribunals is as provided for by the law guiding the conduct of the election. ${ }^{39}$ Also, election petitions are in a class of their own. They are to fast-track the hearing of petition ${ }^{40}$ that are not allowed to be unduly fettered by technicalities. ${ }^{41}$ Also, the jurisdiction of any tribunal to deal with such matters as election petition was a special jurisdiction of a very special nature which did not carry with it the ordinary incidents of appeal in an ordinary civil case. ${ }^{42}$

For instance, the joinder or non-joinder of a party that may be excused under ordinary civil proceedings is fatal to an election petition. In Samamro v. Anka, ${ }^{43}$ the Court of Appeal unequivocally declared that:

Election petitions are not like ordinary civil proceedings. If it were so, then non-joinder of a party or even a misjoinder of a party in a petition like in ordinary civil suit will not affect the jurisdiction of the Court on the suit. In an election petition, the rules creating the right to file the petition, the categories of complaints that can be made and the language and the format of the petition are contained in the statute which also creates the tribunal to preside over the petition are clearly set out in the Decree. Non-Compliance with the rules creating the facility for the petition means there is no petition. It is a misconception to compare the proceedings created in Decree No 5 of 1999 with ordinary proceedings.

It is worthy of note therefore that in view of the peculiar nature of election petitions, guidance in its adjudication is to be drawn only from the relevant statute from which the Court derives its jurisdiction. ${ }^{44}$ It is submitted therefore that the general principles of law applicable in other civil matters are not necessarily applicable to election petitions. In the case of Ezeobi v. Nzeka, ${ }^{45}$ the Court of Appeal rejected the legal argument equating "cause of action" in civil cases to "cause of action" in election petitions. In the case of Falae v. Obasanjo, ${ }^{46}$ the petitioner sought to apply the provisions of the African Charter on Human and People's Rights ${ }^{47}$ to an election petition, the Court of Appeal held that the provisions of the Charter did not apply to election petition proceedings.

While it is incontrovertible that opinion that "election petitions ...[are] special proceedings 'completely divorced and separate', ${ }^{48}$ it shares a common characteristic with ordinary civil cases in matters relating burden and standard of proof.

\subsection{Burden and Standard of Proof in Election Petitions}

The legal burden in an election petition lies on the petitioner. In Buhari v (INEC), ${ }^{49}$ it was held that a petitioner who files a petition under section 145(1) of the Electoral Act has the burden to prove the ground or grounds. This is because he is the party alleging the grounds and he has a duty to prove the affirmative. He is the party who will lose if no evidence is given on the grounds. If the petitioner does not prove his case under section 145(1) of the Act, the action fails.

It thus follows that the Electoral Act Evidence Act imposes a strict burden on the petitioner and the petition fails if the petitioner fails to discharge the duty of proof. ${ }^{50}$ The petitioner's task is made more arduous by the fact that the Election Tribunals do not just require a petitioner, who alleges non-compliance with the Electoral Act, to prove such, but also to prove that the non-compliance substantially affected the result of the election. ${ }^{51}$ Even when the petitioner has had a good shot at discharging these requirements of proof, the Tribunal may yet dismiss

\footnotetext{
39 Peoples Progressive Alliance v. Saraki, (2007) LRECN, 138, 142.

${ }^{40}$ APC v PDP, (2005) 15 NWLR, pt 1481, 1, 25

${ }^{41}$ Nwobodo v. C.C Onoh (1984) $1 \mathrm{SC} 1,195$.

42 Onitiri v. Benson, (1960) 5 FSC 150, 153.

${ }^{43}$ (2000) 1 NWLR pt. 640, 283, 287.

${ }^{44}$ Babalola, Election Law and Practice, above, note 17, 299.

45 (1989) 1 NWLR pt. 98, 478.

46 (1999) 6 NWLR pt. 606, 283, 290.

47 (Ratification and Enforcement) Act Cap 10 Laws of the Federation of Nigeria, 1990.

${ }^{48}$ Obi v. Mbakwe, (1984) NSCC Vol. 15, 127, 326.

49 Above, note 27

${ }^{50}$ Okechukwu v. INEC, above, note 3, p. 299-300

${ }^{51}$ Ibid, 300-301
} 
his petition on the belief that "there are no perfect elections anywhere". ${ }^{52}$

It follows that it is the petitioner who has the onerous duty of proving the allegations set out in the election petition. There exist in law a rebuttable presumption that the result of any election declared by the electoral commission is correct and authentic and so the onus is on the person who denies its correctness and authenticity to rebut the presumption. The Court of Appeal echoed this rebuttable presumption of law in the case of Independent National Electoral Commission v. Ray, ${ }^{53}$ where the petitioner challenged the reliance of the tribunal on the authenticity of the result declared by the Independent National Electoral Commission. The Court of Appeal echoed the position of the law succinctly as follows:

Issue No 2 was whether the tribunal was right to have relied on the results tendered by the petitioner as the authentic results of the election. The learned counsel recapitulated on the exhibits evidencing results tendered by both the petitioner and the respondents and posed the question as to which of the two sets was the authentic result of the election. That under the 1999 Constitution and the Electoral Act 2002, the $1^{\text {st }}$ appellant is the competent authority to conduct elections and issue result. The case of Nwobodo v. Onoh (1984) ISCNLR 1; (1984) ISCI; (1984) LRECN 369 is in point. That any result issued by the $1^{\text {st }}$ appellant is therefore presumed to be correct and authentic. Sections 115, 149 and 150 of the Evidence Act are relevant in support and under reference; also the authority of Sowemimo v. Awobajo \& 2ors, (1999) 7NWLR (pt. 610) 335 (1999) ILRECN, 25....

It is submitted that the rebuttable presumption of correctness in relation to the conduct of elections and issuance of results on the part of the competent authority responsible for same - the Independent National Electoral Commission - is why the onus is on any person who denies its correctness and authenticity to rebut the presumption. This was the legal reasoning of the court in the case of Awuse v. Odili, ${ }^{54}$ where the court emphatically stated that:

The onus of proof in an election petition, like in ordinary civil cases, is on the person questioning the results of an election. The onus is however not static. It shifts from one side of the litigation to the other and vice-versa, from time to time as the petition progresses and eventually rests on the party who would fail if no further evidence is given on either side.

In an election petition it is the party who asserts particular facts in their pleadings that has the onerous onus of proving such facts by adducing credible evidence. Ipso facto, if the party fails to prove such particular facts he asserts, his case will fail. Conversely, if the party successfully proves such facts, the burden of proof that rest on him would have been discharged. The onus of proof in an election petition is in consonance with that required in ordinary cases, which is on the person questioning the result of the election. The proof required therefore is on the balance of probability or the preponderance of evidence. The burden placed on the petitioner is the same as that placed on the plaintiff in civil matters by sections 134 to 136 of the Evidence Act, which states that "[t]he burden of proof shall be discharged on the balance of probabilities in all civil proceedings", ${ }^{55}$ except where the commission of a crime by a party "to any proceeding is directly in issue in any proceeding, civil or criminal, it must be proved beyond reasonable doubt". ${ }^{56}$ Generally, section 136 provides that:

(1) The burden of proof as to any particular fact lies on that person who wishes the Court to believe in its existence unless it is provided by any law that the proof of that fact shall lie on any particular person, but the burden may in the course of a case be shifted from one side to the other.

\footnotetext{
52 Ibid

53 (2004) 2 LRECN, 37, 41.

${ }^{54}$ (2004) 8 NWLR pt. 876, 489.

${ }^{55}$ Section 134

${ }^{56}$ Section 135 (1); it should however be noted that, where there is an admixture of allegation of crime and civil complaint, the complainant is able to succeed by the evidence in the civil part of things if he proves same but not on the criminal Gundiri v. Nyako, [2014] 2 NWLR (Pt. 1391) 211, 251 SC. It has also been held in Omorhirhi v. Enatevwere 19881 NSCC 511, that proof beyond reasonable doubt, does not mean proof beyond any shadow of doubt [the law would fail to protect a sound electoral order if what is required is proof beyond every shadow of doubt
} 
(2) In considering the amount of evidence necessary to shift the burden of proof, regard shall be had by the Court to the opportunity of knowledge with respect to the fact to be proved which may be possessed by the parties respectively.

It is submitted that, whereas the provisions of section 134 of the Evidence Act, states the general rule, that the burden of proof shall be discharged on the balance of probabilities or preponderance of evidence in all civil proceedings, a fortiori, in election petitions. Section 136(1) of the Evidence Act states emphatically that the onus of proof is not static. It oscillates and vacillates like a pendulum, from one side of the litigation to the other and vice versa from time to time as the petition progresses and ultimately rests on the party who would fail if no further evidence is given on either side. As emphasized by Tobi JSC, in Buhari v. INEC, ${ }^{57}$ the "imaginary scale preponderates; and that is the standard, though oscillatory and at times nervous".

In Ajadi v. Ajibola ${ }^{58}$ one of the main issues for determination was whether the Petitioner $/ 1^{\text {st }}$ Respondent discharged the onus of proof on him to enable the burden to shift to the Appellant, who was the declared winner of the Senatorial election in contention. Adamu JCA succinctly stated the following as to whether the onus of proof in election petitions shift:
It is also admitted by the appellant that the results in exhibits "O" show 10 polling stations, exhibit AA (form EC8B) shows 9 wards. On the other hand, exhibit N1 which contains another (form EC8B) for the same ward contains, as shown in exhibit AA, the result of 9 wards. On the other hand, exhibit NI, which contains another form (EC8B) for the same ward contains the results from 10 wards. However, the appellant still argue that the burden of proof lies with the $1^{\text {st }}$ Respondent to show that the alterations so proved by the evidence of PW9 and the supporting exhibits was not made in good faith. This view with respect is contrary to the principles of the burden of proof in civil cases, a fortiori, in election cases which are sui generis and require liberal and lighter proof on the balance of probability or on the preponderance of evidence on the part of the plaintiff. Thus, under section 137 of the Evidence Act (cap 112) Laws of the Federation of Nigeria, 1990, such a burden unlike the one on criminal case is not static but shifts from time to time and lies on a party who would fail if no evidence or further evidence is adduced on the issues.

What is distillable from the illustrative dictum of his Lordship, Adamu JCA in the above case, is that whereas the initial onerous onus of proof of the alteration in the documents tendered on behalf of the petitioner by the PW9 shifted to the $1^{\text {st }}$ Respondent, who was declared winner, it therefore did not lie on the $1^{\text {st }}$ Respondent to insist that for the petitioner to be discharged of the onus on him, he must further establish lack of good faith in the alteration of the documents. Ipso facto, once the petitioner established that the Independent Electoral Commission forms tendered on his behalf contained alterations, the burden of proving that the alterations were made in good faith shifts to the respondent who would lose at that stage if no further evidence is adduced. The Supreme Court in the case of Omoboriowo v. Ajasin $^{59}$ held that the burden of proof is on the person who denies the correctness and authenticity of the return of a candidate to rebut the presumption and that the burden of proof is within the balance of probability or preponderance of evidence.

In that case, the Supreme Court held, on rebutting the correctness of a result declared by a returning officer and on effectively discharging the burden of proof, as follows:

There is in law a rebuttable presumption that the result of any election declared by the returning officer is correct and authentic by virtue of sections 115, 148(C) and 149(1) of Evidence Act and the burden is on the person who denies the correctness and authenticity of the return to rebut the presumption. Where such denial is based on a mere complaint that the petitioner scored a majority of lawful votes, the rebuttal need only to be proved within the balance of probability. Although, neither party produced any of the statements or results showing the votes polled by each candidate at the polling booths, nevertheless, upon a careful and thorough consideration of the totality of the evidence, the trial Court found the petitioner had discharged the burden of proof within the balance of probability because he had produced documentary

\footnotetext{
${ }^{57}$ NSCQR VOLUME 362008 Page 489, 596-597

58 (2004) 1 LRECN 255, 355-356.

59 (1981-1990) LRECN, 332.
} 
evidence all along the line from the receipt of the results from the presiding officers; he had established how the figures for each constituency had been obtained and collated and there was a continuous chain of events leading to the total figures; the evidence of his witnesses was cogent and consistent and related directly to the results obtained from the polling booths. On the other hand, the trial Court found the evidence led by the respondents, failed to connect directly or indirectly the results relied on by the respondents with the polling booths. In consequence, the trial Court preferred the evidence of the witnesses for the petitioner to that of the witnesses for the respondents.

On presumption in favour of the election result and onus on party challenging same and on onus of proof in civil cases the Supreme Court held as follows:

There is a rebuttable presumption that the result of any election declared by the Electoral commission is correct and authentic, and the burden lies on the party that disputes the correctness and authenticity of the result to lead rebuttal evidence.

By reason of the provisions of sections 131(1), (2), 132, 133(1)(2), and 136(1), (2) of the Evidence Act, it is incumbent on the party in a civil case who asserts in his pleading the existence of a particular fact is required to prove such fact by adducing credible evidence. If he fails to do so his case fails. On the other hand, if he succeeds in adducing evidence to prove the pleaded facts, he is said to have discharged the burden of proof that rests on him. The burden then shifts to his adversary, to prove that the fact established by the evidence adduced would not, on the preponderance of evidence result in the court giving judgment in favour of the party. In other words, the burden of proof in civil cases is not static or rigidly on one side as in criminal cases. It shifts from one side to the other, depending on the state of the evidence led in support of each of the party's case. And where an issue is left in serious doubt as to make the court speculate, the party on whom the burden of proof ultimately rests must lose, because he has the burden of establishing the full facts that would persuade the court to find in his favour.

In Ogboru v. Oduaghan, ${ }^{60}$ the Court of Appeal declared that the presumption of election results does not operate independently of some facts which will support it ${ }^{61}$ and based on this, the court held that the inconsistencies, questions and duplications of forms found in respect of the election negate any presumption of correctness or genuineness. ${ }^{62}$ On this score, the court was not persuaded by the arguments of the respondents that, in so far as the first respondent had been declared winner of the election, same enjoyed the presumption of regularity and that the burden of proof was on the petitioner who asserted that there was no election. The Respondents further argued that the petitioner must tender the voters' register for the various polling units, in order to successfully establish their allegations that voters did not vote in the election. Also, that it was the duty of the petitioner to call voters from the various polling units to testify that they could not and indeed did not vote. The court Commenting on this decision, Itse Sagay submitted that the presumption of the correctness of the conduct of elections and declaration of election results was not a sacrosanct doctrine and that certain conditions precedent had to be established before reliance could be placed on the presumption. He therefore applauded the decision on the ground that, " $[t]$ he popular and misleading judicial view had always been the trite and shallow intonement: "He who asserts must prove". ${ }^{63}$

The crust of the decision in Ogboru v. Oduaghan, ${ }^{64}$ as subsequently amplified and followed by the Court of Appeal Agagu v. Mimiko, ${ }^{65}$ is that a petitioner who asserts the negative that no election held, has no burden to plead any documentary proof of their negative averment. On the score, the reasoning of Abdullahi PCA, in the latter case is very instructive. According to him:

The petitioner who asserted that no election held cannot be required to prove the holding of the election by producing its result. It is the Respondent/appellant who alleged that there was a free and fair election that is under obligation to tender the

\footnotetext{
${ }^{60}$ (Unreported) Appeal No. CA/B/EPT/38/10), cited in Itse Sagay, “The Crisis of Election Petitions and Decisions", in a Lecture delivered as part of the Lecture Series on Electoral Integrity on the invitation of the Obafemi Awolowo Institute of Government and Public Policy, at the LCCI Conference Hall Alausa, Ikeja on Tuesday 23rd November, 2010, p. 54.

${ }^{61}$ Citing Amgbare v. Sylva (2009) INWLR (pt 1121) 1, pages 61-62

${ }^{62}$ Ibid.

${ }^{63}$ Above note 60

${ }^{64}$ Ibid

${ }^{65}$ (2009) 1 NWLR pt. 1121, 90, 149.
} 
result of the election in the nature of form EC8A in proof of their assertion the election was freely and fairly conducted and results duly collated and declared. Their failure to do so means they failed to prove that elections were held and therefore, impliedly admitted that there was no election....

The consequence of these decisions is that the onus to prove that election truly held to prove the truth of that assertion against a petitioner that asserts that no election was held, as the Court of Appeal has clearly shown that it is unprepared to extend the presumption of regularity in such circumstance. Furthermore, these decisions show that the consequences of the respondent's failure in this regards will be fatal to their case, as the court would have to nullify the result declare by INEC. Accordingly:

In the face of this lacuna in the respondent's pleadings, the irresistible conclusion is that the said election was afflicted by an irreversible electoral due process deficit. The deficit was so corrosive that it infested the entire process with an incurable or untreatable virus. Any vote returned in such circumstances for any particular voting unit must be invariably, infested with that virus of undue electoral process, Ajadi v. Ajibola (2004) ILRECN 255, 355-356 etc. This is our findings in this case. ${ }^{66}$

\section{Conclusion}

It is distillable from the foregoing that the consent of the governed is the bedrock of democracy which admits of regular and periodic elections. In every election circle in Nigeria, the electorates and not really the politicians end up being the victims of electoral fraud through the diabolical imposition of unpopular candidates on the electorates by a few individuals who stand to benefit themselves from the loyalty of such candidates. It is therefore incumbent on election petition tribunals to always bear in mind, that though the sui generis nature of election petitions precludes the electorates from challenging the result of such imposition, in the ultimate, it is the electorate that deserve justice by restoration of their mandate, freely given, to the candidates they chose. Therefore, to use the words of Chief Justice Hewart, in the case of R. v. Sussex Justices, Ex parte McCarthy, ${ }^{67}$ "it is not merely of some importance, but is of fundamental importance that justice" ... [for the electorate] should not only be done, but should manifestly and undoubtedly be seen to be done". Jacob v. Seminola County Canvassing Board ${ }^{68}$ lends further credence to this by recognising that " $t$ ]he purpose of election laws is to obtain a correct expression of the intent of the voters, without imposing unnecessary and unreasonable restraint on that right".

It is therefore important also for the legislature to make electoral laws, from the beginning to the end, voters' centered. While it will not be possible, for instance, to give voters the locus standi to challenge election result (as that would be too wide a floodgate to contemplate), voters should be made an indispensable part of the process of proving the validity of election results. INEC officials and documents as well as party agents, insofar as there is always the possibility of compromising them, should not be accorded so much place of importance in matters relating to the proof of validity of results.

Also, for the purpose of election laws to be achieved in Nigeria's electoral process without unreasonable restraint, that "shallow intonement" of "he who asserts must prove" as contained in the provisions of in sections 131(1) \& (2), 132, 133(1) \& (2) and 136(1) \& (2) of the Evidence Act must necessarily be amended. It is fundamental to note that it is embodied in this provision ${ }^{70}$ that: “ ... unless it is provided by any law that the proof of that fact shall lie on any particular person...." This can be provided in the Electoral Act if amended or in the alternative, the provisions of sections 131(1) \& (2), 132 and 133(1) \& (2) of the Evidence Act should be amended to expressly admit the application of the burden of proof on the pleadings. This means that whoever asserts the affirmative or the positive must prove on the state of the pleadings.

It does not accord with logic and fairness to expect the petitioner to satisfactorily prove irregularities in the conduct of elections, as the documents he needs to assist him in this regards may not even be readily and fully disclosed to him by INEC. Why should not INEC which is responsible for the conduct of elections and declaration of results be the party that is saddled with the responsibility of proving regularity of conduct of elections. The presumption of regularity in election petition does not and cannot serve the end of justice; it only

\footnotetext{
${ }^{66}$ Ogboru v. Oduaghan, above, note 60

${ }^{67}$ (1924) All ER 233.

${ }^{68}$ (2000) WLR, 1793, 429.

${ }^{69}$ Itse Sagay, "The Crisis of Election Petitions and Decisions", above, note 60, p. 55.

${ }^{70}$ S. 136(1) of the Evidence Act.
} 
aids INEC to be reckless in the conduct of elections, knowing it has the presumption of regularity in its favour.

\section{Copyrights}

Copyright for this article is retained by the author(s), with first publication rights granted to the journal.

This is an open-access article distributed under the terms and conditions of the Creative Commons Attribution license (http://creativecommons.org/licenses/by/4.0/). 